\title{
PEDAGOGY OF PHYSICAL EDUCATION IN URBAN SCHOOLS: A CRITICAL REVIEW
}

\author{
PEDAGOGIA DA EDUCAÇÃO FÍSICA EM ESCOLAS URBANAS: UMA REVISÃO \\ CRÍTICA
}

PEDAGOGÍA DE LA EDUCACIÓN FÍSICA EN ESCUELAS URBANAS: UNA REVISIÓN CRIITICA

\section{Sara Flory}

\section{Keywords:}

Urban area.

Physical education.

Teaching.

Students.

\begin{abstract}
The purpose of this paper was to provide a critical review of the literature related to pedagogy of physical education in urban schools using culturally sustaining pedagogy as a lens. Data was collected via keyword searches, table of contents searches in three U.S.-based journals, and additional references from retrieved articles. The sample included 54 studies which were analyzed in depth and coded for various factors. The findings provide descriptive statistics about the literature, as well as three major themes highlighting cultural relevance in PE, urban student resistance to traditional curriculum, and urban PE to address deficits. The discussion suggests "loving critiques" that could apply to the field of PE, especially in urban contexts.
\end{abstract}

Palavras chave: Área urbana. Educação Física. Ensino. Estudantes.

Palabras clave: Área urbana. Educación Física. Enseñanza. Estudiantes.
Resumo: 0 objetivo deste artigo foi providenciar uma revisão crítica na literatura relacionada com pedagogia da Educação Física em escolas urbanas utilizando como "lente" uma pedagogia sustentada culturalmente. Dados foram coletados por meio da busca de palavras-chaves e nos sumários de três revistas norte-americanas, bem como em adicionais referências recuperadas dos artigos. A amostra incluiu 54 estudos que foram analisados em profundidade e codificados em vários fatores. Os resultados providenciam estatísticas descritivas sobre literatura, bem como três temas principais que destacam a relevância cultural em Educação Física, a resistência de estudantes urbanos ao currículo tradicional e os déficits a serem enfrentados pela Educação Física urbana. A discussão sugere "críticas carinhosas" que podem ser aplicadas no campo da Educação Física, especialmente em contextos urbanos.

Resumen: El objetivo de ese artículo fue presentar una revisión crítica en la literatura relacionada con pedagogía de la Educación Física en escuelas urbanas usando como "lente" una pedagogía sostenida culturalmente. Los datos fueron recolectados por medio de la búsqueda de palabras-clave y en los índices de tres revistas norteamericanas, al mismo tiempo en referencias adicionales recuperadas de los artículos. La muestra incluyó 54 estudios que fueron analizados a profundidad y codificados en varios factores. Los resultados presentan estadísticas descriptivas y también tres temas principales, que destacan la relevancia cultural en Educación Física, la resistencia de los alumnos urbanos al currículo tradicional y los déficits a ser enfrentados por la Educación Física urbana. La discusión sugiere "críticas cariñosas" que pueden ser aplicadas al campo de la Educación Física, especialmente en contextos urbanos.
*University of South of Florida. Tampa, Florida, USA.

E-mail: sbflory@usf.edu

Received 29 May 2019

Accepted 04 September 2019 Published 16 November 2019

DOI: hitps://doi.org/10.22456/1982-8918.96230 (c) (1) (8) Licence 


\section{INTRODUCTION}

While schools in urban communities with large student populations have existed since the industrial revolution, the concept of "urban education" that launched a boom of research and reform initiatives stemmed from the White flight following World War II. Several policies in the U.S. introduced during the 1940s and 1950s (i.e., the GI Bill of Rights, policies and tax breaks encouraging home ownership, etc.) allowed citizens to further their education and purchase homes in suburban areas (METTLER, 2005). As a result, cities became populated with mostly poor, minority residents with fewer economic opportunities (WILSON, 2012). Businesses and industries also moved out of the cities, leaving fewer residents and a lower property tax base, limiting the expenditures for schools in cities (METLER, 2005). The term urban education was coined to address the "[...] adjustments needed to prepare city children for an overwhelming technical society in a state of rapid change" (RIDINI; MADDEN, 1975, p. 5).

Research about the conditions of urban schools, the challenges of teaching in urban schools, and the characteristics of students in urban schools followed in large supply. Journals related to the study of urban schools (i.e., Urban Education, The Urban Review) began in the 1960s. Studies on the achievement gap between suburban and urban students (related to standardized test scores, graduation rates, advanced placement enrollment, and college acceptance rates) began in the 1960s, along with various theories and explanations for the existence of this gap (LADSON-BILLINGS, 2006). Author and educator Jonathon Kozol received the National Book Award for his 1967 book Death at an Early Age, where he recounts his experience teaching poor Black children in an overcrowded Boston public elementary school. Interventions and ethnographies dissecting the nuances of education in urban schools produced theories, curricular models, and best practices, all to educate the children attending those schools and to potentially overcome the achievement gap between urban students and their suburban and rural counterparts.

Over the next several decades, research about urban communities and schools highlighted concerns related to rates of poverty, crime, violence and gang activity, qualifications of teachers, school facilities that were insufficient, outdated or worn, and teacher turnover. Gradually, the language used to describe urban schools and the students attending them included terms such as culturally and/or linguistically "diverse" (despite demographics to suggest otherwise), "disadvantaged," "marginalized," "low-performing" or "at-risk" (MILNER, 2008; WATSON, 2011; WEINER, 2003). Urban students and schools were portrayed negatively in research (NOGUERA, 1996; WATSON, 2011), as unmotivated, unwilling to learn, and with uninvolved, uninterested parents (WATSON, 2011).

Meanwhile, even today, teachers in the U.S. remain mostly White, middle-class women, while the population of U.S. school children continues to diversify. In the 1970 s, nearly $80 \%$ of U.S. school children were White, yet by 2014, racially diverse students comprised the majority of U.S. school children for the first time (STRAUSS, 2014). Teachers, school administrators, scholars and the media shy away from pointing out segregation in urban schools. Kozol (2005) wrote, "Schools in which as few as 3 or 4 percent of students may be white or Southeast Asian or of Middle Eastern origin, for instance - and where every other child in the building is Black or Hispanic - are referred to as "diverse" ( p. 43). Also, even the way in which "urban schools" can be identified has shifted. Milner (2012) acknowledges "urban schools" are now classified based on who attends the schools, rather than the physical location or number of students. In 
a recent visit to a school district that appeared rural by many descriptors (demographic data, location, etc.), administrators took Milner to an "urban school" within the district and asked for advice on how to address the urban issues affecting this school's performance (MILNER, 2012). The school population was largely Black and Hispanic. There were issues with truancy, low test scores, low motivation, and low parent involvement. These were the descriptors that came to define "urban schools." These issues had little to do with the students who attended the school and had more to do with the policies enacted by the adults in charge. However, the school leaders had identified this school and the related issues as "urban." In short, the term "urban" often describes schools and students in ways that are considered inferior to suburban schools and White students. "Urban" - at least in U.S. contexts - has become synonymous for places where poor, non-White students live and attend schools, and do not meet the standards of White students in suburban schools.

Although research on physical education (PE) in urban schools may not be as vast as broader research on urban education, there is a critical mass of scholarship examining $P E$ in these settings. Many of the challenges that general education teachers face in urban schools are also encountered by PE teachers: limited facilities, equipment, instructional time, or professional development; students that appear uninterested or disengaged; and lack of support from administrators (COTHRAN; ENNIS, 1997; ENNIS, 1995; MCCAUGHTRY et al., 2006). This has provided plenty of fodder for researchers within the discipline to examine, intervene, and compare PE in urban schools to other settings over the past several decades. The purpose of this paper is to provide a critical review of the literature related to pedagogy of physical education in urban schools.

\section{THEORETICAL FRAMEWORK}

Culturally sustaining pedagogy (CSP; ALIM; PARIS, 2017; PARIS, 2012; PARIS; ALIM, 2014) was the lens through which I reviewed the literature related to pedagogy of physical education in urban schools. This framework may be especially fitting to examine the literature, considering research on cultural distance existing among urban students and their teachers (FLORY; MCCAUGHTRY, 2011). CSP is an extension of the previous work by multiple scholars who called for culturally relevant pedagogies when working with students in urban schools (GAY, 2000; LADSON-BILLINGS, 1995), but better captures the value of the culture in question, rather than comparing it to a standard.

\footnotetext{
CSP seeks to perpetuate and foster - to sustain - linguistic, literate, and cultural pluralism as part of schooling for positive social transformation. CSP positions dynamic cultural dexterity as a necessary good, and sees the outcome of learning as additive rather than subtractive, as remaining whole rather than framed as broken, as critically enriching strengths rather than replacing deficits. Culturally sustaining pedagogy exists wherever education sustains the lifeways of communities who have been and continue to be damaged and erased through schooling (ALIM; PARIS, 2017, p.1).
}

This theoretical framework is helpful to use when examining the literature related to physical education in urban schools, especially as the term "urban" has evolved from a term to describe the locale or population of a school into a condition to overcome. Alim and Paris (2017, p. 2) state: 
[...] our languages, literacies, histories, and cultural ways of beings as people and communities of color are not pathological. Beginning with this understanding [...] allows us to see the fallacy of measuring ourselves and the young people in our communities solely against the White middle-class norms of knowing and being that continue to dominate notions of educational achievement.

CSP builds from the concepts of cultural relevance pedagogies by offering three loving critiques (ALIM; PARIS, 2017; PARIS; ALIM, 2014). These loving critiques aim to respectfully identify gaps in previous theories and approaches, as well as identify ways to remain critical and dynamic in a changing society. The first loving critique addresses the notions of asset pedagogies such as culturally relevant pedagogy (LADSON-BILLINGS, 1995), culturally responsive pedagogy (GAY, 2000), or cultural congruence (AU; KAWAKAMI, 1994). These pedagogies identified the practices of communities of color as assets and resources when enacting the dominant norms in schools that align with White, middle-class values (ALIM; PARIS, 2017). Paris (2012, p. 95) stated:

Relevance and responsiveness do not guarantee in stance or meaning that one goal of an educational program is to maintain heritage ways and to value cultural and linguistic sharing across difference, to sustain and support bi- and multilingualism and bi- and multiculturalism...necessary for success and access in our demographically changing U.S. and global schools and communities.

The second loving critique offered through CSP is the examination of research that views culture as static or fixed, rather than understanding the dynamic ways in which young people experience race and ethnicity (ALIM; PARIS, 2017). Rather than looking at how previous generations enacted racial and ethnic differences, Alim and Paris (2017) encourage the use of CSP to view culture as dynamic and shifting. The authors state:

As youth continue to develop new, complex, and intersecting forms of racial/ethnic identification in a world where cultural and linguistic recombinations flow with purpose, we need pedagogies that speak to our shifting cultural realities, or as Pennycook (2007) put it, pedagogies that 'go with the flow' (ALIM; PARIS, 2017, p. 9).

The third loving critique suggested by Alim and Paris (2017) is to reflect on cultural practices and communities that may become problematic, even in using progressive pedagogies to engage students of color. That is to say, CSP provides space to question progressive pedagogies to ensure that they do not reify oppressive practices such as hegemonic discourses regarding gender, race, sexuality, ability, or citizenship (ALIM; PARIS, 2017):

Our goal is to find ways to support and sustain what we know are remarkable ways with language, literacy, and cultural practice, while at the same time opening up spaces for students themselves to critique the ways that they might be - intentionally or not - reproducing discourses that marginalize members of our communities, (ALIM; PARIS, 2017, p. 11).

\section{METHODS}

Scholarship for this review was identified via keyword searching Google Scholar, ERIC, and ProQuest using the search terms physical education in urban schools, urban physical education, and pedagogy urban physical education. Table of contents searches were conducted for three U.S. journals (Journal of Teaching in Physical Education, Quest, and Research 
Quarterly for Exercise and Sport) to locate studies that did not populate through keyword searches. Additional studies were retrieved from reference lists. Inclusion criteria for this critical review were (1) studies published in English, (2) study focused on urban students, practicing teachers, or schools, and (3) studies focused on school physical education. Studies that had a physical activity, dance, or sport focus were not included in this critical review, nor were studies that focused on multicultural education or cultural competence, unless urban schools or students were an explicit focus. Likewise, studies that focused on teacher preparation for urban contexts were not included. This is not to say that these topics and foci are not helpful for examining and understanding the field of urban physical education, however, these topics are beyond the scope of this critical review.

The initial sample of scholarship for this critical review included 89 citations. After reviewing the abstracts for inclusion and exclusion criteria, the sample was narrowed to 54 citations which were analyzed in depth. Once manuscripts were identified for inclusion, they were coded for various factors including the type of manuscript (i.e., empirical research, literature review, theoretical, etc.), the participants (i.e., students, teachers, or other), the type of research (i.e., qualitative, quantitative, or mixed methods), and the publication outlet (i.e., U.S.-based PE journals, international PE journals, and journals outside of PE). Notes about each manuscript were made to determine the main issues raised by the authors, as well as the takeaway message of each manuscript.

Abstracts and notes about each manuscript were analyzed using constant comparison and inductive analysis (CORBIN; STRAUSS, 2008; LECOMPTE; SCHENSUL, 1999) to identify relationships and organize the codes into themes. Themes were shared with a peer debriefer and re-examined for negative cases to increase trustworthiness.

\section{FINDINGS}

The scholarship analyzed for this critical review spanned the years 1959 through 2018. Of the 54 citations reviewed, one was a report, two were books, and the remaining 51 were manuscripts published in journals. Five of the studies were conducted internationally. The majority of the participants in the studies were teachers in urban schools $(n=19)$. Urban students were the participants in 17 of the studies, and 11 studies worked with both teachers and students. Most of the studies utilized qualitative research methods $(n=23)$ to carry out the study. Quantitative research design was utilized in 17 of the studies, and mixed methods research was mentioned in 5 of the studies. Of the 51 manuscripts published in journals, approximately $50 \%$ were published in U.S. physical education journals ( $n=26$; e.g., Journal of Teaching in Physical Education, Research Quarterly for Exercise and Sport). The remainder of the manuscripts were either published in an international physical education journal ( $n=13$; e.g., Physical Education and Sport Pedagogy, Sport, Education and Society) or in a journal outside the field of physical education $(n=12)$.

When reviewing the literature related to the pedagogy of physical education in urban schools, three major themes emerged. These themes included cultural relevance in PE, urban student resistance to traditional curriculum, and urban PE to address deficits. 


\subsection{CULTURAL RELEVANCE IN PE}

An overwhelming finding was the issue of cultural relevance in urban PE. Nearly a third of the studies reviewed $(n=17)$ addressed culturally relevant curriculum and pedagogy. Calls for curriculum that met the needs of students began as early as the 1970s. Ridini and Madden (1975, p.94) wrote:

In planning comprehensive programs for their students, inner city physical educators need to take into account such factors as the interests and needs of students in a changing, cybernetic society; activities that have high potential for carry-over to students' leisure hours; socioeconomic and emotional conditions; the physical conditions of the schools in terms of facilities, equipment, and supplies; the educational philosophy of the schools; and the evaluative tools utilized in determining whether students are receiving viable, comprehensive, and relevant programs.

A lack of cultural relevance became evident, as students needs were not met and teachers felt underprepared to enact relevant pedagogy.

In five studies, researchers shared that urban students were disengaged in PE due to curriculum that was not relevant to their interests, or was not accessible (COTHRAN; ENNIS, 1997; COTHRAN; ENNIS, 1998; ENNIS et al, 1997; JAMES; COLLIER, 2011; WILLIAMS; WOODHOUSE, 1996). In many of these studies, conflicting values related to the goals of schooling and education existed between teachers and students, as well as curriculum that privileged certain groups of students over others. Relevant curriculum to engage students in PE is important in all school contexts, but is exacerbated in schools where the cultural backgrounds of students and teachers are vastly different (FLORY; MCCAUGHTRY, 2011).

Thirteen studies shared findings related to teachers' experiences with providing or enacting curriculum that was relevant to urban students (CHEPYATOR-THOMSON et al., 2008; COTHRAN; ENNIS, 1998; CULP; CHEPYATOR-THOMSON 2011; CULP, 2011; ENNIS, 1994, 1995, 1999a; ENNIS; CHEN, 1995; FLORY; MCCAUGHTRY, 2011; KULINNA et al., 2006; MCCAUGHTRY et al., 2006; SCHMIDLEIN et al., 2014; RIDINI; MADDEN, 1975). In several studies, teachers admitted that they were not prepared to teach students from cultural backgrounds different than their own, so they struggled to provide relevant curriculum for their students. Other teachers focused on building positive, trusting relationships to learn how to better serve students.

\subsection{URBAN STUDENT RESISTANCE TO TRADITIONAL CURRICULUM}

A second theme from the literature was the resistance to traditional PE curriculum from students in urban schools. Fourteen studies focused on alternative curricular options, whether that was incorporating student voice and choice in curriculum or specific culturally relevant pedagogies.

In eight studies, students responded positively to alternative curricular approaches (AZZARITO; HILL, 2013; AZZARITO et al., 2017; ENNIS, 1999b; ENNIS et al., 1999; FITZPATRICK, 2013; DEGLAU; O'SULLIVAN, 2006; WRIGHT; BURTON, 2008; WRIGHT et al., 2010). These curricular models included alternative approaches to learning and teaching sport (i.e., Sport Education, Teaching for Personal and Social Responsibility, Sport for Peace), as well as critical approaches to PE that empower youth to be more engaged. 
Additionally, six studies identified the importance of providing urban students with voice and choice in their PE programs (COTHRAN; ENNIS, 2000; ENNIS; MCCAULEY, 2002; HOLT, et al. 2012; LI et al., 2008; SHEN et al., 2008; WRIGHT; LI, 2009). These studies highlighted how providing options for urban students (in terms of what was taught and how they learned), encouraging autonomy, and engaging youth as resources were essential to involving students in PE classes.

Alternative curricular approaches and providing voice and choice in PE may garner positive responses in many PE contexts (urban, suburban, and rural). However, these approaches are well-received in urban schools because of the disconnect between school culture and the values of students that attend urban schools (ENNIS; CHEN, 1995).

\subsection{URBAN PE TO ADDRESS DEFICITS}

Lastly, literature of PE in urban schools often takes on a deficit perspective, meaning, $P E$ is a means to address deficits in the lives of urban youth. Fourteen studies took a deficit approach, which counters a CSP framework. Broader health concerns, teaching social skills, or saving students from societal or community issues become the main concern here.

Four studies used ties to health concerns as justification for research on students in urban schools. These health concerns center around standards such as reaching recommended daily physical activity levels via step counts or minutes of moderate-to-vigorous physical activity (MVPA), combatting obesity and overweight in urban youth, reducing cardiovascular disease and sedentary behaviors, and increasing fitness levels. (CASTILLO et al., 2015; DAUENHAUER; KEATING, 2011; FARDY et al., 2004; SKALA et al., 2012). It is critical to note that research and debates connecting PE and public health concerns has existed for decades (GARD; WRIGHT, 2001; KIRK, 2006; SALLIS; MCKENZIE, 1991), and is quite relevant in urban settings that judge non-White youth according to White standards.

Eight of the studies in this sample referenced the need to teach social skills in urban physical education. These social skills included conflict resolution, social responsibility, moral reasoning, empathy, sportsmanship, fair play, knowing appropriate school routines, cooperation, and leadership (BRANTA; GOODWAY, 1996; CHOI; CHEPYATOR-THOMSON, 2012; ENNIS; ROSS; CHEN, 1992; ENNIS; CHEN, 1995; MILLER et al., 1997; SCHMIDLEIN et al., 2014; SHARPE et al., 1995; RIDINI; MADDEN, 1975). Some of these studies were specific interventions in urban schools, while other studies identified a more explicit focus on social skills by urban teachers. Social skills have been highlighted in broader PE research as especially appropriate to include in curricula due to the interactive and less-formal atmosphere (compared to the classroom) of PE lessons (GOUDAS; MAGOTSIOU, 2009; JACOBS; KNOPPERS; WEBB, 2013; MCHUGH, 1995).

Finally, two studies noted how PE could be a vehicle for urban students to overcome the adversities of living in poor, urban communities (BRIGGS, 1970; RIDINI; MADDEN, 1975). These studies cited that PE and athletics gave urban youth more opportunities for success in life and reduced drop-out rates, and identified teacher-student relationships as a key to whether inner city students chose to apply for college, go to work, or dropped out. In broader research, evidence linking PE to positive academic performance is inconclusive (RASBERRY et al., 2011). 


\section{DISCUSSION}

A detailed review of literature related to the pedagogy of physical education in urban schools reveals that as a field, we may not be any closer to truly meeting the needs of students in physical education in urban schools than we were four decades ago. Using the critical lens of culturally sustaining pedagogy (CSP) (PARIS, 2012), it becomes increasingly clear that despite our best intentions, we may need to consider a different approach. The themes from the literature in this review (cultural relevance in $\mathrm{PE}$, urban student resistance to traditional curriculum, and using urban PE to address deficits) highlight how most PE in urban schools overwhelmingly fails to engage students, and does not fully value students in urban schools. As Paris (2012, p. 95) wrote,

We need a new term and a new approach that will not only more accurately embody some of the best past and present research and practice but will also offer preservice and in-service teachers a way of both naming and conceptualizing the need to meaningfully value and maintain the practices of their students in the process of extending their students' repertoires of practice to include dominant language, literacies, and other cultural practices.

Perhaps "loving critiques" (ALIM; PARIS, 2017) are in order for the field of physical education as we consider how to move forward in meeting the needs of youth in urban schools.

Alim and Paris (2017) first critiqued asset pedagogies as not being enough to sustain the cultural practices of Black and Hispanic students, that these pedagogies simply used the traditions of these cultures to attain the White, middle-class norms common in schools. Similarly, culturally relevant pedagogies have been referenced in urban PE literature, however most of these references identify how curriculum and pedagogy are not culturally relevant to students, or that teachers do not know how to enact culturally relevant pedagogy. Very few examples of effective culturally relevant pedagogy exist within the literature, yet calls for additional research, teacher preparation and professional development to assist teachers in enacting culturally relevant pedagogy are plentiful. When we "other" youth in urban schools (BORRERO et al., 2012; KUMASHIRO, 2000), we inadvertently assign White, middle-class schools and students as the aspirational ideal. While there is no argument that cultural dissonance occurs when teachers and students have differing cultural and ethnic backgrounds (HODGE et al., 2012), tolerating slang in classes and finding activities that urban youth can engage in outside of school PE does not seem to fully meet their needs. As Alim and Paris (2017, p.3) state,

For too long, scholarship on "access" and "equity" has centered implicitly or explicitly around the White-gaze-centered question: How can "we" get "these" working class kids of color to speak/write/be more like middle-class White ones (rather than critiquing the White gaze itself that sees, hears, and frames students of color in everywhichway as marginal and deficient)?

When we examine our practices through this lens, culturally relevant pedagogies and culturally competent teachers do not seem to be enough to overcome the presence of Whiteness and White middle-class values in schools (FINE, 2004).

The second loving critique addressed by Alim and Paris (2017) in support of CSP was to re-examine the dynamic and shifting nature of culture. The authors write, "[...] it is crucial that we understand the ways in which young people are enacting race, ethnicity, language, literacy and their engagement with culture is always shifting and dynamic" (ALIM; PARIS, 2017, p. 7). These 
authors cite Pennycook (2007), calling for pedagogies that "go with the flow" to connect with the ever-changing interactions that urban youth have within and among culture. This critique seems to advise against tradition and heritage for the sake of cultural conservation, promoting instead more complex interpretations of race, ethnicity and culture. Likewise, resistance to traditional PE curriculum and positive responses to alternative and critical approaches to PE suggests a stronger connection to more progressive interpretations of PE and physical activity culture. Although student resistance and disengagement has been studied previously in PE literature (ENNIS, 1999a; KINCHIN; O'SULLIVAN, 2003), promoting student voice may especially connect to the constantly changing realities of youth culture in diverse urban communities. In response to these findings, teachers and teacher educators could benefit from critically questioning their approach to teaching PE, including why particular activities are included or excluded, if student choice and voice is considered in their curriculum, and if their approach offers relevance for their students.

The final loving critique that Alim and Paris (2017) suggest to enact CSP is to look inward to identify what practices within even the most progressive pedagogies may promote oppressive practices and raise critical consciousness. In PE, there is plenty of research to suggest that traditional, sport-based PE supports a multitude of oppressive practices (AZZARITO et al., 2006; DEWAR, 1990; KIRK; SPILLER, 1994; SQUIRES; SPARKES, 1996), yet there is little critique of many models-based practices that are also supported by research (LANDI; FITZPATRICK; MCGLASHAN, 2016). Furthermore, when well-intentioned researchers who study urban youth with the aim of reversing public health concerns (i.e., obesity and physical inactivity) do not critically examine the broader socioeconomic concerns that may lead to such issues (i.e. poverty, food deserts, etc.), their efforts to solve these issues within the confines of school PE may be further marginalizing a CSP framework and these students.

Future research related to physical education pedagogy in urban schools must radically reconsider what students in urban school truly need to feel and become engaged, and valued as students of color, not as comparisons to a White, middle-class ideal. Those who engage in research with urban populations should consider whether their investigations simply promote individual research agendas, align with funded health-based practices, or seek to sustain practices meaningful to students in urban schools. Students enter classrooms with their own agency; they are experts in their own lives, knowledgeable about their own experiences and communities. As teachers and researchers, we must offer opportunities to promote this additive perspective. As Alim and Paris (2017, p. 12) state,

We are in many ways at the asset-based, critical pedagogical edge. For us, as we hope is clear by now, we are not interested in offering pedagogical quick fixes or "best practices" that teachers can drop into the same old tired curriculum that deadens the souls of vast numbers of children of color in U.S. schools.

\section{REFERENCES}

ALIM, H. Samy; PARIS, Django. What is culturally sustaining pedagogy and why does it matter. In: PARIS, Django; ALIM, H. Samy. Culturally sustaining pedagogies: Teaching and learning for justice in a changing world. New York: Teachers College, 2017. p. 1-21. 
AU, Kathryn; KAWAKAMI, Alice. Cultural congruence in instruction. In: HOLLINS, Etta; KING, Joyce; HAYMAN, Warren. Teaching diverse populations: Formulating a knowledge base. Albany, New York: State University of New York, 1994. p. 5-24.

AZZARITO, Laura; HILL, Joanne. Girls looking for a 'second home': Bodies, difference and places of inclusion. Physical education and sport pedagogy, v. 18, n.4, p. 351-375, 2013.

AZZARITO, Laura; SIMON, Mara; MARTTINEN, Risto. 'Up against Whiteness': rethinking race and the body in a global era. Sport, education and society, v. 22, n. 5, p. 635-657, 2017.

AZZARITO, Laura; SOLMON, Melinda; HARRISON JR, Louis. "... If I had a choice, I would...." A feminist poststructuralist perspective on girls in physical education. Research quarterly for exercise and sport, v. 77, n. 2, p. 222-239, 2006.

BORRERO, Noah; YEH, Christine; CRUZ, Crivir; SUDA, Jolene. School as a context for "othering" youth and promoting cultural assets. Teachers college record, v. 114, n. 2, p. 1-37, 2012.

BRANTA, Crystal; GOODWAY, Jacqueline. Facilitating social skills in urban school children through physical education. Peace and conflict, v.2, n. 4, p.305-319, 1996.

BRIGGS, Paul. The opportunity to be relevant: An eloquent, hard-hitting plea for a revitalized program of physical education and athletics for urban youth. Journal of health, physical education, recreation, v. 41, n. 5, p. 41-45, 1970.

CASTILLO, Jacqueline; CLARK, B. Ruth; BUTLER, Carling; RACETTE, Susan. Support for physical education as a core subject in urban elementary schools. American journal of preventive medicine, v. 49, n. 5, p. 753-756, 2015.

CHEPYATOR-THOMSON, Jepkorir Rose; KIM, Sunhwi; XU, Furong; SCHMIDLEIN, Robert; NA, Jaekwon; CHOI, Wonseok; YEO, Connie. Multiethnic diversity in K-12 US physical education: A synthesis of literature in kinesiology-based journals (1995-2005). The ICHPER-SD journal of research, v. 3, n. 1, p. 33-39, 2008.

CHOI, Wonseok; CHEPYATOR-THOMSON, Rose. Physical education teachers teaching in a multicultural setting: A case study of teacher knowledge and practice. Journal of physical education and sport, v. 12, n. 4, p. 436, 2012.

CORBIN, Juliet; STRAUSS, Anselm. Techniques and procedures for developing grounded theory: Basics of qualitative research, 3 ed. Thousand Oaks, CA, USA: Sage, 2008.

COTHRAN, Donetta; ENNIS, Catherine. Students' and teachers' perceptions of conflict and power. Teaching and teacher education, v. 13, n. 5, p. 541-553, 1997.

COTHRAN, Donetta; ENNIS, Catherine. Curricula of mutual worth: Comparisons of students' and teachers' curricular goals. Journal of teaching in physical education, v. 17, n. 3, p. 307-326, 1998.

COTHRAN, Donetta; ENNIS, Catherine. Building bridges to student engagement: Communicating respect and care for students in urban high schools. Journal of research and development in education, v. 33, n. 2, p. 106-117, 2000.

CULP, Brian, CHEPYATOR-THOMSON, Jepkorir Rose. Examining the culturally responsive practices of urban primary physical educators. Physical educator, v. 68, n. 4, p. 234-253, 2011. 
CULP, Brian. The archetypes and philosophical motivations of urban elementary physical educators. ICHPER-SD journal of research, v. 6, n. 1, p. 40-47, 2011.

DAUENHAUER, Brian; KEATING, Xiaofen. The influence of physical education on physical activity levels of urban elementary students. Research quarterly for exercise and sport, v. 82, n. 3, p. 512-520, 2011.

DEGLAU, Dena; O'SULLIVAN, Mary. Chapter 3: The effects of a long term professional development program on the beliefs and practices of experienced teachers. Journal of teaching in physical education, v. 25, n. 4, p. 379-396, 2006.

DEWAR, Alison. Oppression and privilege in physical education: Struggles in the negotiation of gender in a university programme. In: KIRK, David; TINNING, Richard. Physical education, curriculum and culture: Critical issues in the contemporary crisis. London: Falmer , 1990. p. 67-100.

ENNIS, Catherine. Urban secondary teachers' value orientations: Delineating curricular goals for social responsibility. Journal of teaching in physical education, v. 13, n. 2, p. 163-179, 1994.

ENNIS, Catherine. Teachers' responses to noncompliant students: The realities and consequences of a negotiated curriculum. Teaching and teacher education, v. 11, n. 5, p. 445460, 1995.

ENNIS, Catherine. Students' experiences in sport-based physical education: More than apologies are necessary. Quest, v. 48, n. 4, p. 453-456, 1996.

ENNIS, Catherine. Creating a culturally relevant curriculum for disengaged girls. Sport, education and society, v. 4, n. 1, p. 31-49, 1999a.

ENNIS, Catherine. Communicating the value of active, healthy lifestyles to urban students. Quest, v. 51, n. 2, p. 164-169, $1999 \mathrm{~b}$.

ENNIS, Catherine; MCCAULEY, M. Terri. Creating urban classroom communities worthy of trust. Journal of curriculum studies, v. 34, n. 2, p. 149-172, 2002.

ENNIS, Catherine; ROSS, Juanita; CHEN, Ang. The role of value orientations in curricular decision making: A rationale for teachers' goals and expectations. Research quarterly for exercise and sport, v. 63, n. 1, p. 38-47, 1992.

ENNIS, Catherine; CHEN, Ang. Teachers' value orientations in urban and rural school settings. Research quarterly for exercise and sport, v.66, n.1, p. 41-50, 1995.

ENNIS, Catherine; SOLMON, Melinda; SATINA, Barbara; LOFTUS, Susan; MENSCH, James; MCCAULEY, M. Terri. Creating a sense of family in urban schools using the "Sport for Peace" curriculum. Research quarterly for exercise and sport, v. 70, n. 3, p. 273-285, 1999.

ENNIS, Catherine, COTHRAN, Donetta, DAVIDSON, Keren, LOFTUS, Susan, OWENS, Lynn, SWANSON, Lisa, HOPSICKER, Peter. Implementing curriculum within a context of fear and disengagement. Journal of teaching in physical education, v. 17, n. 1, p. 52-71, 1997.

FARDY, Paul; AZZOLLINI, Ann; HERMAN, Ariela. Health-based physical education in urban high schools: the PATH program. Journal of teaching in physical education, v. 23, n. 4, p. 359371, 2004. 
FINE, Michelle. Witnessing whiteness/gathering intelligence. In: FINE, Michelle; WEIS, Lois; PRUITT, Linda Powell; BURNS, April. Off white: Readings on power, privilege, and resistance.

2. ed. New York: Routledge, 2004. p. 245-256.

FITZPATRICK, Katie. Critical pedagogy, physical education and urban schooling. New York: Peter Lang, 2013.

FLORY, Sara; MCCAUGHTRY, Nate. Culturally relevant physical education in urban schools: Reflecting cultural knowledge. Research quarterly for exercise and sport, v. 82, n. 1, p. 49-60, 2011.

GARD, Michael; WRIGHT, Jan. Managing uncertainty: Obesity discourses and physical education in a risk society. Studies in philosophy and education, v. 20, n. 6, p. 535-549, 2001.

GAY, Geneva. Culturally responsive teaching: Theory, research, and practice. New York: Teachers College, 2000.

GOUDAS, Marios; MAGOTSIOU, Evmorfia. The effects of a cooperative physical education program on students' social skills. Journal of applied sport psychology, v. 21, n. 3, p. 356364, 2009.

GREEN, Ken. Philosophies, ideologies and the practice of physical education. Sport, education and society, v. 3, n. 2, p. 125-143, 1998.

HODGE, Sam; LIEBERMAN, Lauren; MURATA, Nathan. Essentials of teaching physical education: Culture, diversity, and inclusion. Scottsdale, AZ: Holcom Hathaway , 2012.

HOLT, Nicholas; SEHN, Zoe; SPENCE, John; NEWTON, Amanda; BALL, Geoff. Physical education and sport programs at an inner city school: exploring possibilities for positive youth development. Physical education and sport pedagogy, v. 17, n. 1, p. 97-113, 2012.

JACOBS, Frank; KNOPPERS, Annalies; WEBB, Louisa. Making sense of teaching social and moral skills in physical education. Physical education and sport pedagogy, v. 18, n. 1, p. 1-14, 2013.

JAMES, Alisa; COLLIER, Douglas. An ecological examination of an urban sixth grade physical education class. Physical education and sport pedagogy, v. 16, n. 3, p. 279-293, 2011.

KINCHIN, Gary; O'SULLIVAN, Mary. Incidences of student support for and resistance to a curricular innovation in high school physical education. Journal of teaching in physical education, v. 22, n. 3, p. 245-260, 2003.

KIRK, David. Curriculum history in physical education: A source of struggle and a force for change. In: SPARKES, Andrew. Research in physical education and sport: Exploring alternative visions. London: RoutledgeFalmer, 1992. p. 210-230.

KIRK, David. The 'obesity crisis' and school physical education. Sport, education and society, v. 11, n. 2, p. 121-133, 2006.

KIRK, David, SPILLER, Barbara. Schooling the docile body: Physical education, schooling and the myth of oppression. Australian journal of education, v. 38, n. 1, p. 78-95, 1994.

KOZOL, Jonathan. Death at an early age: The destruction of the hearts and minds of negro children in the Boston public schools. Boston: Houghton Mifflin, 1967. 
KOZOL, Jonathan. Still separate, still unequal. Harper's magazine, v. 9, p. 41-55, 2005.

KULINNA, Pamela Hodges; MCCAUGHTRY, Nate; COTHRAN, Donetta; MARTIN, Jeffrey. What do urban/inner-city physical education teachers teach? A contextual analysis of one elementary/ primary school district. Physical education and sport pedagogy, v. 11, n. 1, p. 45-68, 2006.

KUMASHIRO, Kevin. Toward a theory of anti-oppressive education. Review of educational research, v. 70, n. 1, p. 25-53, 2000.

LADSON-BILLINGS, Gloria. Toward a theory of culturally relevant pedagogy. American educational research journal, v. 32, n. 3, p. 465-491, 1995.

LADSON-BILLINGS, Gloria. From the achievement gap to the education debt: Understanding achievement in US schools. Educational researcher, v. 35, n. 7, p. 3-12, 2006.

LANDI, Dillon; FITZPATRICK, Katie; MCGLASHAN, Hayley. Models based practices in physical education: A sociocritical reflection. Journal of teaching in physical education, v. 35, n. 4, p. 400-411, 2016.

LECOMPTE, Margaret; SCHENSUL, Jean. Designing and conducting ethnographic research Lanham, MD: Altamira, 1999. v.1.

LI, Weidong; WRIGHT, Paul; RUKAVINA, Paul; PICKERING, Molly. Measuring students' perceptions of personal and social responsibility and the relationship to intrinsic motivation in urban physical education. Journal of teaching in physical education, v. 27, n. 2, p. 167-178, 2008.

MCCAUGHTRY, Nate; BARNARD, Sara; MARTIN, Jeffrey; SHEN, Bo; KULINNA, Pamela Hodges. Teachers' perspectives on the challenges of teaching physical education in urban schools: The student emotional filter. Research quarterly for exercise and sport, v. 77, n. 4, p. 486-497, 2006.

MCHUGH, Elaine. Going 'beyond the physical': Social skills and physical education. Journal of physical education, recreation and dance, v. 66, n. 4, p. 18-21, 1995.

METTLER, Susan. Soldiers to citizens: The GI Bill and the making of the greatest generation. New York: Oxford University, 2005.

MILLER, Stephen; BREDEMEIER, Brenda; SHIELDS, David. Sociomoral education through physical education with at-risk children. Quest, v. 49, n. 1, p. 114-129, 1997.

MILNER IV, H. Richard. Disrupting deficit notions of difference: Counter-narratives of teachers and community in urban education. Teaching and teacher education, v. 24, n. 6, p. 1573-1598, 2008.

MILNER IV, H. Richard. But what is urban education? Urban education, v. 47, n. 3, p. 556-561, 2012.

NOGUERA, Pedro. Confronting the urban in urban school reform. The urban review, v. 28, n. 1 , p. 1-19, 1996.

PARIS, Django. Culturally sustaining pedagogy: A needed change in stance, terminology, and practice. Educational researcher, v. 41, n. 3, p. 93-97, 2012.

PARIS, Django, ALIM, H. Samy. What are we seeking to sustain through culturally sustaining pedagogy? A loving critique forward. Harvard educational review, v. 84, n. 1, p. 85-100, 2014. 
PENNYCOOK, Alastair. Language, localization, and the real: Hip-hop and the global spread of authenticity. Journal of language, identity, and education, v. 6, n. 2, p. 101-115, 2007.

RASBERRY, Catherine; LEE, Sarah; ROBIN, Leah; LARIS, B.; RUSSELL, Lisa; COYLE, Karin; NIHISER, Allison. The association between school-based physical activity, including physical education, and academic performance: a systematic review of the literature. Preventive medicine, v. 52, p. S10-S20, 2011.

RIDINI, Leonard; MADDEN, John. Physical education for inner city secondary schools. New York: Harper and Row, 1975.

SALLIS, James; MCKENZIE, Thomas. Physical education's role in public health. Research quarterly for exercise and sport, v. 62, n. 2, p. 124-137, 1991.

SCHMIDLEIN, Robert; VICKERS, Brad; CHEPYATOR-THOMSON, Rose. Curricular issues in urban high school physical education. Physical educator, v. 71, n. 2, p. 273-302, 2014.

SHARPE, Tom; BROWN, Marty; CRIDER, Kim. The effects of a sportsmanship curriculum intervention on generalized positive social behavior of urban elementary school students. Journal of applied behavior analysis, v. 28, n. 4, p. 401-416, 1995.

SHEN, Bo; MCCAUGHTRY, Nate; MARTIN, Jeffrey. Urban adolescents' exercise intentions and behaviors: An exploratory study of a trans-contextual model. Contemporary educational psychology, v. 33, n. 4, p. 841-858, 2008.

SKALA, Katherine; SPRINGER, Andrew; SHARMA, Shreela; HOELSCHER, Deanna; KELDER, Steven. Environmental characteristics and student physical activity in PE class: Findings from two large urban areas of Texas. Journal of physical activity and health, v. 9, n. 4, p. 481-491, 2012.

SQUIRES, Sarah; SPARKES, Andrew. Circles of silence: Sexual identity in physical education and sport. Sport, education and society, v. 1, n. 1, p. 77-101, 1996.

STRAUSS, Valerie. For the first time, minority students expected to be majority in U.S. public schools this fall. The Washington Post. Retrieved from: https://www.washingtonpost.com/news/ answer-sheet/wp/2014/08/21/for-first-time-minority-students-expected-to-be-majority-in-u-spublic-schools-this-falll, 2014, Aug 21. Accessed: 18 Jul. 2019.

WATSON, Dyan. "Urban, but not too urban": Unpacking teachers' desires to teach urban students. Journal of teacher education, v. 62, n. 1, p. 23-34, 2011.

WEINER, Lois. Why is classroom management so vexing to urban teachers? Theory into practice, v. 42, n. 4, p. 305-312, 2003.

WILLIAMS, Anne; WOODHOUSE, Jeremy. Delivering the discourse-urban adolescents' perceptions of physical education. Sport, education and society, v. 1, n. 2, p. 201-213, 1996.

WILSON, William. The truly disadvantaged: The inner city, the underclass, and public policy. Chicago: University of Chicago, 2012.

WRIGHT, Paul; BURTON, Suzanne. Implementation and outcomes of a responsibility-based physical activity program integrated into an intact high school physical education class. Journal of teaching in physical education, v. 27, n. 2, p. 138-154, 2008.

WRIGHT, Paul; LI, Weidong. Exploring the relevance of positive youth development in urban physical education. Physical education and sport pedagogy, v. 14, n. 3, p. 241-251, 2009. 
WRIGHT, Paul; LI, Weidong; DING, Sheng; PICKERING, Molly. Integrating a personal and social responsibility program into a wellness course for urban high school students: Assessing implementation and educational outcomes. Sport, education and society, v. 15, n. 3, p. 277298, 2010. 